\title{
Effect of Varying Levels of Palm Oil Decanter Cake on Feed Intake, Growth Performance and Carcass Characteristics of Kacang Goats
}

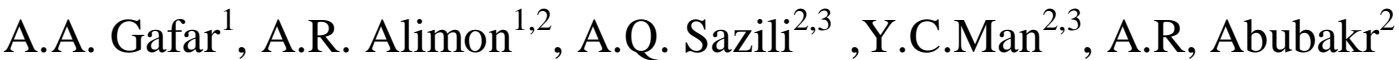 \\ ${ }^{1}$ Institute of Tropical Agriculture, ${ }^{2}$ Department of Animal Science, ${ }^{3}$ Halal Product Research Institute, University \\ Putra Malaysia, Malaysia
}

\begin{abstract}
The improvement of the animal production in Malaysia need the animal population number also to raise accordingly, the cost of animals feeds is intenselyassociated with the cost of animal production as feeds comprise $70 \%$ of total cost (Jelan, 2005). To reduce the cost, local feed resources could be an alternative.in Malaysia, a huge amount of biomass is produced from the process of palm oil extraction. Among these byproducts, palm oil decanter cake (PODC) is a potential, available, cheap feed resource for ruminants (Wan Zahari et al., 2012).Therefore, the objective of presentexperiment was to evaluate the feed intake, body weight $(B W)$ and carcass characteristics of Kacang goats fed varying levels of PODC.
\end{abstract}

\subsection{Introduction}

In the year 2008, the highest percentage of global vegetable oil and fats were traded by Malaysia, where an incessant interest pertaining to the usage of the oil palm waste(Lam et al., 2009)

\subsection{Materials and Methods}

\subsubsection{The experimental location}

The experiment was conducted in the laboratory and the metabolic pens at the faculty of agriculture, University Putra Malaysia.

\subsubsection{Animals the management}

Twenty four male one yearKacang goats with initial body weight (BW) of $16.9 \pm 1.14 \mathrm{~kg}$ (mean \pm SD) were used for the study. The goats were penned for 3 weeks, and during this period they were injected by antiparasites.

\subsubsection{Treatments and experimental design}

Twenty four male one year Kacang goats were randomly assigned to one of four dietary treatments for 105 days. Goats were fed basal diet containing Napier grass ad libitumfor the first 15 days and then assigned to one of four concentrate diets (treatments; approximately $16 \% \mathrm{CP}$ on dry matter basis) and the decanter cake ratio was $0 \%: 10 \%: 20 \%: 30 \%$ on dry matter basis (DM), The treatments included concentrate mix of soya bean meal and corn (T1, control), 10\% decanter cake (T2), 20\% decanter cake (T3), 30\% decanter cake (T4) (Table 1.

Table 1 Ingredient and chemical composition of experimental concentrates diets

\begin{tabular}{lccccc}
\hline Item & T1 & T2 & T3 & T4 & Napier grass \\
\hline Ingredients, \% DM & & & & & \\
$\quad$ Corn grain & 78 & 68 & 58 & 48 & \\
Soybean meal & 21 & 21 & 21 & 21 & \\
Decanter cake & 0 & 10 & 20 & 30 & \\
CaCo3 & 0.5 & 0.5 & 0.5 & 0.5 & \\
Vitamin-mineral premix & 0.5 & 0.5 & 0.5 & 0.5 & \\
Chemical composition, \% DM & & & & & \\
$\quad$ Dry matter & 94.9 & 96.2 & 96.2 & 95.7 & 91.2 \\
Organic matter & 86.7 & 86.7 & 87.7 & 87.1 & 83.4 \\
Crude protein & 16.6 & 16.8 & 16.5 & 16.2 & 2.7 \\
Ether extract & 4.5 & 6.8 & 7.6 & 7.7 & 1.1 \\
$\quad$ Acid detergent fiber & 11.2 & 17.1 & 30.0 & 34.2 & 54.3 \\
$\quad$ Neutral detergent fiber & 41.1 & 54.1 & 60.6 & 62.5 & 73.2 \\
\hline
\end{tabular}


T1 (control diet), T2 (10\% decanter cake with concentrate mix), T3 (20\% decanter cake with concentrate mix), and $\mathrm{T} 4$ (30\% decanter cake with concentrate mix)

\subsubsection{Daily feed intakes}

PODC had daily offer to the experimental goats once a day at $800 \mathrm{~h}$, and the napier grass was given after the (PODC) consumption. Daily feed offer and refusal balanced were recorded and weigh to measurethe daily feed intake for each goat. Meanwhile, the waterhad available free access to each goat. Feed samples offer and the refused feed for each goat were collected and kept for measuringits chemical composition.

\subsubsection{Chemical composition of the feed}

Composite samples of given feed, balanced feed and feces were ground to pass a $1 \mathrm{~mm}$ sieve screen using a laboratory mill and analyzed for DM, CP, EE and ash (AOAC, 1990). Acid detergent fiber (ADF), neutral detergent (NDF) and acid detergent lignin (ADL) were determined according to (Van Soest \& Robertson, 1985)(chapter 3).

\subsubsection{Carcass characteristics}

As the procedure of (Galal, 1979)the last day of the experiment, four goats from each groups were selected randomly for slaughter after fasted overnightbandrecorded the goats weighed before slaughter, while fasting over a night.Initial weight for fasted goats and their hot carcass weights were recorded immediately after slaughter. Directly after slaughter, non-carcass components (head, heart, lung, liver, spleen, kidneys, kidney fat, and gastro-intestinal tract fat) were removed and weighed. The stomach (rumen, reticulum, abomasum andomasum) and postruminal tract (small intestine, large intestine and caecum) were removed and weighed separately. The contents of the stomach and postruminal tract were removed, washed and weighed to obtain the weight of the empty stomach and postruminaltract. Carcasses were chilled overnight at $4{ }^{\circ} \mathrm{C}$ and cold carcass weight was determined the next morning. According to (Van Z et al., 1969) the dressing percentage as cold carcass weight relative to fasted body weight being calculated.

\subsubsection{Statistical analysis}

The data collected were subjected to the one way analysis of variance using the general linear model procedure of (SAS, 2003).

\subsection{Results}

\subsubsection{Chemical composition of the experimental feeds}

Palm oil decanter cake used in this experiment contained approximately $12.8 \% \mathrm{CP}$ on dry matter basis, as shown in the table 1, and the decanter cake ratio was 0\%:10\%:20\%:30\% on dry matter basis (DM) contrarily, the ingredients used in the concentrate mix had relatively high $\mathrm{CP}$, low NDF and ADF contents, control compared to the supplemented treatments, respectively, for T2, T3 and T4. Supplementation improved $(\mathrm{P}<0.001) \mathrm{CP}$ intake, and the $\mathrm{CP}$ intake increased $(\mathrm{P}<0.001)$ with level of supplementation.

\subsubsection{Daily feed intakes}

The total DM intake of experimental goats supplemented with the high level of PODC was almost similar compared to that for non-supplemented goats ( $(\mathrm{P}>0.05)$ (Table 2), PODCDM, CP and NDF intakes were higher $(P<0.001)$ in non-supplemented than in supplemented goats. The DM, CP and NDF intakes of concentrate mix was no change with the level of PODC increased, while the total DM intake increased. There was no significant difference $(\mathrm{P}>0.05)$ in total DM intake between supplemented goats Table 2 .

Table 2 Dietary ingredients, means ( \pm SEM), dry matter intake and chemical composition of PODC and concentrate mix diets in goats fed different levels of PODC

\begin{tabular}{lcccccc}
\hline Parameter & T1 & T2 & T3 & T4 & SEM & P value \\
\hline Ingredients, \% DM & & & & & & \\
$\quad$ Corn grain & 78 & 68 & 58 & 48 & & \\
$\quad$ Soybean meal & 21 & 21 & 21 & 21 & & \\
Decanter cake & 0 & 10 & 20 & 30 & & \\
CaCo3 & 0.5 & 0.5 & 0.5 & 0.5 & & \\
$\quad$ Vitamin-mineral premix & 0.5 & 0.5 & 0.5 & 0.5 & & \\
Dry matter intake (g/day) & & & & & & \\
Napier grass & $263.3^{\mathrm{a}}$ & $244.8^{\mathrm{ab}}$ & $241.8^{\mathrm{ab}}$ & $249.3^{\mathrm{b}}$ & 8.35 & 0.0035 \\
$\quad$ CMD & $186.1^{\mathrm{a}}$ & $149.8^{\mathrm{b}}$ & $147.83^{\mathrm{b}}$ & $136.8^{\mathrm{b}}$ & 6.429 & 0.0002 \\
& & & & & &
\end{tabular}




PODC
Total intake (DM \%)
Chemical composition (DM \%)
OM
CP $(\%$ DM)
EE $(\%$ DM)
ADF $(\%$ DM)
NDF $(\%$ DM)
ADL (\% DM)

$\begin{array}{llllll}0.0^{\mathrm{c}} & 69.6^{\mathrm{b}} & 105.1^{\mathrm{a}} & 113.6^{\mathrm{a}} & 5.31 & 0.0001 \\ 449.5 & 465.16 & 483.66 & 474.3 & 13.73 & 0.3629 \\ & & & & & \\ 61.81 & 93.81 & 93.85 & 93.35 & 0.993 & 0.4297 \\ 16.5 & 16.1 & 16.2 & 16.1 & 1.002 & 0.1757 \\ 64.31 & 64.9 & 66.08 & 64.51 & 1.03 & 0.638 \\ 46.91^{\mathrm{a}} & 45.1^{\mathrm{a}} & 46.0^{\mathrm{ab}} & 45.1^{\mathrm{b}} & 0.935 & 0.0235 \\ 19.88 & 17.83 & 16.21 & 15.50 & 0.991 & 0.7363 \\ 16.1 & 11.26 & 6.81 & 3.29 & 0.726 & 0.6251\end{array}$

T1, napier grass with concentrate mix; T2, 10\% decanter cake with concentrate mix; T3, 20\% decanter cake with concentrate mix; T4, 30\% decanter cake with concentrate mix. PODC palm oil decanter cake, CMDconcentrate mix

The ${ }^{\mathrm{a}-\mathrm{c}}$ Means with different superscripts in rows are significantly different $(\mathrm{P}<0.05)$.

DM dry matter, OM organic matter, $\mathrm{CP}$ crude protein, EE ether extract, ADF acid detergent fiber, NDF neutral detergent fiber, ADL acid detergent lignin (\% DM)

$\mathrm{SEM}=$ standard error of mean $(n=6)$

\subsubsection{Body weight gain}

The experimental goats had almost similar daily BW gain T1group compared to T2 and T3, but had slightly lower in T4 groupas shown in the table 3, had indicated that the crude protein in PODC is totally satisfied the maintenance requirement of the goats. The supplemented goats had no significant differences $(\mathrm{P}>0.05)$ FCE than the non-supplemented ones, and no significant differences $(\mathrm{P}>0.05)$ were observed between the supplemented groups. Table 3 .

Table 3.Body weight changes ofKacang goats fed supplemented with varying level of PODC.

\begin{tabular}{lcccccc}
\hline Body weight changes & T1 & T2 & T3 & T4 & SEM & P value \\
\hline Initial BW (kg) & 17.2 & 17.0 & 16.5 & 16.9 & 0.5269 & 0.816 \\
Final BW (kg) & 20.98 & 22.0 & 21.5 & 21.8 & 0.5117 & 0.546 \\
BW gain (g day) & $37.8^{\mathrm{b}}$ & $50.0^{\mathrm{a}}$ & $50.0^{\mathrm{a}}$ & $49.0^{\mathrm{a}}$ & 0.2184 & 0.0016 \\
Feed intake (DM g/day) & 449.5 & 465.2 & 483.7 & 474.33 & 20.2 & 0.6231 \\
Gain : feed (DM) & 0.084 & 0.107 & 0.103 & 0.103 & 0.012 & 0.537
\end{tabular}

$\mathrm{T} 1=$ napier grass with concentrate mix; $\mathrm{T} 2=10 \%$ decanter cake with concentrate mix; $\mathrm{T} 3=20 \%$ decanter cake with concentrate mix; $\mathrm{T} 4=30 \%$ decanter cake with concentrate mix. The ${ }^{\mathrm{a}-\mathrm{b}}$ Means with different superscripts in rows are significantly different $(\mathrm{P}<0.05) ; \mathrm{ns}=$ not significant; $\mathrm{P}=$ significance level and $\mathrm{SEM}=$ standard error of mean.

The positive mean daily BW gain in the supplemented goats in this experiment showed that the crude protein and energy in PODC is totally more than enough to cover the body nutrients requirement and the maintenance of the experimental goats.

The daily BW gain and final BW for the experimental were no different $(\mathrm{P}>0.05)$ for supplemented goats compared to the control (Table 4). The supplemented goats had no significant differences (P>0.05) FCE than the non-supplemented ones, and no significant differences $(\mathrm{P}>0.05)$ were observed among the supplemented treatments.

\subsubsection{Carcass characteristic parameters}

Slaughter weight and hot and cold carcass weights were all higher $(\mathrm{P}<0.05)$ for T1 and T2, T3 and T4. However, dressing percentage was not different $(\mathrm{P}>0.05)$ among treatments. As a percentage of the cold carcass weight, the ratio of carcass was higher $(\mathrm{P}<0.05)$ for all groups. Carcass characteristics of goats supplemented with PODC shows similarity with the non supplemented goats (Table 4).

The edible carcass offal of Kacang goats fed with napier grass supplemented with different levels of decanter cake is significant with the control group (table 5).The similarity of comestible offal weigh observed for the supplemented Kacang goats with PODC and the similarity of offal weigh observed for the supplemented goats with PODCcould be due to the similar digestible nutrients resulting in proportionally similar gut content as a consequence. 
Table 4.Carcass characteristics of Kacang goats fed supplemented with varying levels of decanter cake and concentrate mix..

\begin{tabular}{lllllll}
\hline Body weight changes & T1 & T2 & T3 & T4 & SEM & P value \\
& & & & & & \\
\hline Initial BW (kg) & 16.6 & 17.25 & 16.82 & 16.47 & 0.571 & 0.786 \\
Final BW (kg) & 21.8 & 22.22 & 21.5 & 21.8 & 0.739 & 0.9194 \\
BW gain (kg) & 5.20 & 4.97 & 4.67 & 5.32 & 0.468 & 0.7752 \\
Slaughter weight (kg) & 21.92 & 22.12 & 21.7 & 21.1 & 0.744 & 0.786 \\
Empty body weight (kg) & 18.55 & 18.10 & 18.30 & 18.40 & 0.532 & 0.943 \\
Hot carcass weight (kg) & 12.20 & 11.70 & 10.68 & 10.77 & 0.449 & 0.058 \\
Cold carcass weight (kg) & 11.9 & 11.8 & 11.75 & 12.1 & 0.443 & 0.089 \\
Dressing percentage & 55.75 & 55.3 & 53.3 & 56.75 & 0.901 & 0.642 \\
\hline
\end{tabular}

T1, napier grass with concentrate mix; T2, $10 \%$ decanter cake with concentrate mix; T3, 20\% decanter cake with concentrate mix; T4, 30\% decanter cake with concentrate mix.

The ${ }^{\mathrm{a}-\mathrm{c}}$ Means with different superscripts in rows are significantly different $(\mathrm{P}<0.05)$

$\mathrm{SEM}=$ standard error of mean $(n=4)$

Table 5 Non-carcass components of Kacang goats supplemented with varying levels of decanter cake and concentrate mix.

\begin{tabular}{|c|c|c|c|c|c|c|}
\hline Non-carcass components & $\mathrm{T} 1$ & $\mathrm{~T} 2$ & $\mathrm{~T} 3$ & $\mathrm{~T} 4$ & SEM & $P$ value \\
\hline Head & 1381 & 1298 & 1363 & 1328 & 53.98 & 0.707 \\
\hline Heart & $85^{\mathrm{b}}$ & $85^{\mathrm{b}}$ & $79.2^{\mathrm{a}}$ & $83^{\mathrm{b}}$ & 1.95 & 0.0009 \\
\hline Liver & $251^{\mathrm{b}}$ & $316^{\mathrm{ab}}$ & $336^{\mathrm{a}}$ & $364^{\mathrm{a}}$ & 16.96 & 0.0034 \\
\hline Lungs & $235^{\mathrm{b}}$ & $270^{\mathrm{ab}}$ & $323^{\mathrm{a}}$ & $290^{\mathrm{ab}}$ & 19.225 & 0.0435 \\
\hline Spleen & 48 & 52 & 56 & 42 & 4.88 & 0.265 \\
\hline Kidney & 73 & 64 & 72 & 72 & 5.79 & 0.674 \\
\hline Kidney fat & 74.2 & 64 & 78 & 70 & 8.46 & 0.687 \\
\hline Abdominal fat & $309.3^{\mathrm{b}}$ & $343^{\mathrm{ab}}$ & $362^{\mathrm{a}}$ & $346 .^{\mathrm{ab}}$ & 9.45 & 0.130 \\
\hline Reticulo-rumen & 481.4 & 405 & 459 & 371.37 & 56.78 & 0.527 \\
\hline Omasum-abomasum & $123^{\mathrm{b}}$ & $129^{\mathrm{ab}}$ & $155^{\mathrm{a}}$ & $119^{\mathrm{b}}$ & 11.92 & 0.234 \\
\hline Intestines & 591 & 598 & 567 & 561 & 35.73 & 0.857 \\
\hline Tail & 33 & 34 & 39 & 33 & 2.657 & 0.362 \\
\hline Testis & $128^{\mathrm{c}}$ & $169^{\mathrm{b}}$ & $194^{\mathrm{a}}$ & $186^{\mathrm{ab}}$ & 5.22 & 0.001 \\
\hline Blood & 954 & 986 & 1061 & 979 & 67.82 & 0.716 \\
\hline Total non-carcass components & 3310.5 & 3430 & 3702 & 3433 & 138.04 & 0.280 \\
\hline
\end{tabular}

$\mathrm{T} 1$ = napier grass with concentrate mix; $\mathrm{T} 2=10 \%$ decanter cake with concentrate mix; $\mathrm{T} 3=20 \%$ decanter cake with concentrate mix; $\mathrm{T} 4=30 \%$ decanter cake with concentrate mix. The ${ }^{\mathrm{abc}}$ Means with different superscripts in rows are significantly different $(\mathrm{P}<0.05) ; * * *(\mathrm{P}<0.001)$; ** $\mathrm{P}<0.01)$, * $(\mathrm{P}<0.05)$; $\mathrm{ns}=$ not significant; $\mathrm{SL}=$ significance level and SEM = standard error of mean.

\subsection{Discussions}

The CP content of PODC used in the present study was comparable to the CP content of POME reported by (Singh et al., 2010). Similar for the NDF and ADF content of PODC in this study was comparable to the result of (Seephueak et al., 2011). High NDF and ADF in the PODC used in the current study are related to its lower CP content. Indeed, (Singh et al., 2010)reported low CP content in oil seed cakes with high cell wall contents. 
The increase in CP intake with increase in level of concentrate mix supplementation could be a function of higher total DM intake and higher CP content in the concentrate mix. This by itself might have promoted higher total DM consumption in the supplemented goats, and one of the effects of protein supplementation is improvement of access to feeds by rumen microbes, DMI per kg BW presentation of intake also showed adequate consumption of the mixed diets as it falls within the recommended value of $25-50 \mathrm{~g} / \mathrm{kg}$ BW for tropical multipurpose goats (Devendra, 1985).

Growth performance and intake data were presented in table 5.1. Total feed intake was similar in all groups, however, T3 and T4 had higher PODC intake compare to T1 and T2.

Nutrient digestibility was not significantly different among dietary treatments except for acid detergent fiber which was higher in $\mathrm{T} 1$ and $\mathrm{T} 2$ in contrast to $\mathrm{T} 4$ this might be due to changes in rumen microbes structure and population as reported by (Abubakr et al., 2012). Final body weight andweight gain was lower $(\mathrm{P}<0.001)$ in T1 compare to other treatments suggesting that up to $30 \%$ could be included in the diets of growing goats without any adverse effects. This finding is in accordance with data published by (Seephueak et al., 2011) who concluded that the optimum level of PODC should not exceed $30 \%$.

Similar results been demonstrated by (Vadiveloo, 1986)the forage intake not significantly depressed at all level of supplementation with POME, but slightly increased the total intake, when fed Kacang and Kacang x German Fawn crossbred goats with Leucaenaleucocephala and Napier grass, which fed the experimental goats fed POME.

The increase in $\mathrm{CP}$ consumption with increase in ratio of concentrate supplementation could be a function of the increase ofthe total PODC consumption and the increase in CP intake with increase the ratio of concentrate mix diet supplementation could be a function of higher total DM consumption. One of the effects of protein supplementation is improvement of access to feedby rumen microbes, and this by itself might have promoted higher total DM consumption in the supplemented goats.

In the current experiment there is an agreement with the same results for feed trials for POS fed experimental cattle's, the results give the same recommendations is that the maximum ratio could be use is $30 \%$ (Seephueak et al., 2011)

PODC had improved the protozoa fermentations due to high contents of $\mathrm{CP}$ and that could enhanced the diets rumen microbes, DM per kg BW presentation of intake also showed adequate consumption of the concentrate mix diets (Solomon et al. 2008).

Supplemented goats and its positive mean daily BW gain in this experiment shows the PODC, grass and concentrate mix had the enough adequate of the maintenance requirement of Kacanggoats. These finding had been estimated earlier as the content of PODC CP (12.8\%) (Afdal et al., 2012)and apparent DM digestibility $(62.3 \%)$ in the treatment was more than adequate to meet maintenance requirement of the goats. (Van Soest et al.1994) demonstrated that BW gain is not impaired if the level of CP in a given diet is more than 8\%. Similarly high BW gain in supplemented goats could be due to high energy and protein intake, as compare with the same results in Thailand cattles fed with varying levels of POS(Seephueak et al., 2011)with similar daily BW gain recorded for the treatment T2 and T3 is almost similar to control treatment could be due of equality of $\mathrm{CP}$ percentages with control group, and that shows the protein and energy in the PODC is similar to the protein and energy in the concentrate mix in $\mathrm{T} 1$ as well.

However, the same results been recorded at levels of PODC supplementations with $30 \%$ was recoded the best ratio for supplemented goats, that is totally agreed with same author.

Respectively, in cattle supplemented with $300 \mathrm{~g}$ wheat bran and $300 \mathrm{~g}$ POME, which is comparable to the results of the present study.

However, Initial BW (kg), final BW (kg), BW gain (kg), slaughter weight ( $\mathrm{kg}$ ), empty body weight (kg), hot carcass weight $(\mathrm{kg})$ and cold carcass weight $(\mathrm{kg})$ non-carcass components were not significantly different $(\mathrm{p}>0.05)$

The Carcass dressing percentage in supplemented goats was similar for non-supplemented goats that totally agree with (Ensminger, 2002) and the range was between 37\%-55\%. 
Similar with non-carcass components were not significantly different ( $p>0.05$ ) for head,spleen, kidney, kidney fats, reticulo-rumen, intestines, tail and blood in all groups accordingly. Table 5.

\subsection{Conclusions}

It was concluded that palm oil decanter cake could be included in the diets of goats up $30 \%$. These findings can help to find the solution for the animals feed crisis.

\section{References}

[1]. Abubakr, A. R., Alimon, A. R., Yaakub, H., Abdullah, N. \& Ivan, M. (2012). Digestibility, rumen protozoa, and ruminal fermentation in goats receiving dietary palm oil by-products. Journal of the Saudi Society of Agricultural Sciences (In press).

[2]. Afdal, A., Kasim, A., Alimon, A. R. \& Abdullah, N. (2012). Some chemical properties of oil palm decanter meal. African Journal of Biotechnology 11(27), 7128-7134.

[3]. AOAC. (1990). Official Method of Analysis. 15th Edn., Association of Official Analytical Chemists, Washington, DC., USA.

[4]. Devendra, C. (1985). Non conventional feed resources in Asia and the Pacific. FAO regional office for Asia and the Pacific, 2nd edition, Bangkok, Thailand.

[5]. Ensminger, M. E. (2002). Sheep and Goat Science. 6th ed. Interstate Publisher, Inc., Danville, IL,USA.

[6]. Galal, E. S. E. (1979). A study on fattening Ethiopian sheep: 2: Performance of Adal lambs on supplemented grazing. Ethiopian Journal of Agricultural Science, 1, 99-107.

[7]. Jelan, Z. A. (2005). Recent advances in animal nutrition in Malaysia: its relevance and importance for farming system in Indonesia. In Seminar nasional teknologi peternakan dan veteriner, $12-13$ September 2005. Bogor, Indonesia.

[8]. Lam, M. K., Tan, K. T., Lee, K. T. \& Mohamed, A. R. (2009). Malaysian palm oil: Surviving the food versus fuel dispute for a sustainable future. Renewable and Sustainable Energy Reviews, 13(6-7), 1456-1464.

[9]. SAS. (2003). Statistical analytical system, Cary, NC, USA.

[10]. Seephueak, W., Ngampongsai, W. \& Chanjula, P. (2011). Effects of palm oil sludge in concentrate on nutrient utilization and rumen ecology of thai native cattle fed with hay. Songklanakarin Journal of Scieince and Technolology, 3(33), 271-280.

[11]. Singh, R. P., Ibrahim, M. H., Esa, N. \& Iliyana, M. S. (2010). Composting of waste from palm oil mill: a sustainable waste management practice. Reviews in Environmental Science and Bio/Technology, 9(4), 331-344.

[12]. Vadiveloo, J. (1986). The effect of alkali treatment of straw and dried palm-oil sludge on the intake and performance of goats of varying genotype. Agricultural Wastes, 18, 233-245.

[13]. Van Soest, P. J. \& Robertson, J. B. (1985). Analysis of forage and fibrous foods. In A laboratory manual for animal science, Cornell University Press. Ithaca, New York, US.

[14]. Van Z, J. H. M., Von la Chevallerie, M. \& Skinner, J. D. (1969). A note on the dressing percentage in the springbok (Antidorcas marsupialis, Zimmerman) and impala (Aepyceros melampus). Proceedings of South African Society Animal Production. 199-200.

[15]. Wan Zahari, M., Alimon, A. R. \& Wong, H. K. (2012). Utilization of oil palm co-products as feedsfor livestock in Malaysia. In Biofuel co-products as livestock feed-Opportunities and challenges, edited by Harinder P.S, ed. FAO. Makkar,Rome, pp. $243-262$. 